\title{
Konsep dasar kebijakan pendidikan
}

\author{
Fadiyah Elwijaya ${ }^{1}$, Vivi Mairina ${ }^{\left.1^{*}\right)}$, Nurhizrah Gistituati ${ }^{1}$ \\ ${ }^{1}$ Universitas Negeri Padang, Indonesia
}

\section{Article Info \\ Article history: \\ Received Apr $02^{\text {nd }}, 2021$ \\ Revised May $07^{\text {th }}, 2021$ \\ Accepted Jun $10^{\text {th }}, 2021$}

\section{Keyword:}

Concept

Policy

Education

\begin{abstract}
Education policy is important in the process of achieving national education goals so that an understanding of the basic concepts of education policy is needed in order to produce pro-active education policies and problem solving. The purpose of writing this article is to examine the scope of education policy which consists of the meaning of education policy, components of education policy, characteristics of educational policies and implementation of educational policies. This writing methodology uses literature study methodology. The writing of this article was carried out by reviewing 26 journals related to education policy. The results of the study found that education policy is a policy related to the education sector in the process of elaborating the vision and mission of education in order to achieve educational goals through strategic steps in the implementation of education. The education policy component consists of five, namely objectives, plans, programs, decisions, and impacts. The characteristics of education policy are that of having educational objectives, fulfilling legal-formal aspects, having an operational concept, being made by the authorities, being able to be evaluated and having a systematic approach. The approach to implementing educational policy consists of a structural approach, a procedural and managerial approach, a behavioral approach and a political approach.
\end{abstract}

(C) 2021 The Authors. Published by IICET.

This is an open access article under the CC BY-NC-SA license

(https://creativecommons.org/licenses/by-nc-sa/4.0)

\section{Corresponding Author:}

Vivi Mairina,

Universitas Negeri Padang

Email: vivijundrial@gmail.com

\section{Pendahuluan}

Kebijakan berasal dari kata yunani yaitu polis yang berati kota. Kebijakan berhubungan dengan ide mengenai pengelolaan organisasi (Kiwang et al, 2014). Lebih lanjut kebijakan merupakan suatu aktivitas formal yang diselenggarakan oleh lembaga (pemerintah) dengan maksud untuk mencapai tujuan yang telah ditetapkan (Ramdhani and Ramdhani, 2017). Kebijakan juga dapat diartikan sebagai sebuah keputusan yang dikeluarkan oleh pemerintah untuk masyarakat dan berlaku umum (Nasarudin, 2016).

Kebijakan yang mengatur tentang sistem pendidikan disebut dengan kebijakan pendidikan. Kebijakan pendidikan sudah banyak dilahirkan yang bertujuan untuk mempermudah dan memfasilitasi penyelenggara pendidikan dan masayarakat untuk dapat mengembangkan pendidikan secara inovatif untuk mencapai tujuan pendidikan nasional (Junaid, 2016). Pencapaian tujuan pendidikan berkaitan dengan faktor-faktor yang saling berhubungan diantaranya yaitu faktor pendidik, faktor peserta didik, faktor tujuan pendidikan, faktor alat pendidikan dan faktor lingkungan (Dewi, 2016). Maka dapat disimpulkan bahwa pendidikan merupakan sebuag sistem yang sistematis yang saling berkaitan antar sub sistem. Sistem tidak akan berjalan apabila salah 
satu sub sistem bermasalah yang akan mengakibatkan tidak maksimalnya fungsi sub sistem tersebut dalam mencapai tujuan pendidikan yag telah ditetapkan.

Tujuan pendidikan Indonesia terdapat pada sistem pendidikan nasional. Sistem pendidikan nasional merupakan sistem yang mengintergrasikan setiap satuan dan aktivitas pendidikan yang saling berhubungan antara satu dengan yang lainnya dalam mencapai tujuan pendidikan nasional (Hakim, 2016). Tujuan pendidikan nasional ini dirumuskan melalui sebuah kebijakan yang disebut dengan kebijakan pendidikan. Kebijakan pendidikan di Indonesia telah mengalami beberapa perubahan dnegan tujuan untuk menghasilkan sistem pendidikan nasional yang mencirikan bangsa Indonesia. Pada tahun 2003 ditetapkanya Undangundang nomor 20 tahun 2003 mengenai sistem pendidikan nasional. Dikeluarkannya undang-undang tersebut menandakan bahwa pemerintah Indonesia serius dalam mencapai tujuan pendidikan melalui sebuah kebijakan pendidikan.

Pencapaian tujuan pendidikan berpengaruh terhadap mutu pendidikan (Azhari and Kurniady, 2016). Mutu pendidikan tersebut dapat dikelola berdasarkan kebijakan pendidikan yang telah ditetapkan. Maka dari hal ini dibuktikan bahwa kebijakan pendidikan memiliki keterkaitan satu sama lain yang berdampak kepada proses berjalanyan sistem pendidikan tersebut. Maka dalam hal kebijakan pendidikan harus dirumuskan dengan memperhatikan ketercapaian tujuan pendidikan tersebut.

Pemerintah sebagai penyelengara pendidikan harus merumuskan kebijakan pendidikan yang bersifat pro aktif dan problem solving bsehingga permasalahan yang berkaitan dengan pencapaian tujuan pendidikan dapat diatasi (Istanti, 2018). Berbicara sistem pendidikan bukanlah hal yang mudah, Sistem pendidikan merupakan sebuah sistem yang kompleks dan berhubungan antara satu dengan yang lainya. Oleh sebab itu diperlukannya pemahaman mengenai kebijakan pendidikan agar penyelenggara pendidikan mampu merumuskan kebijakan yang sesuai dengan sistem pendidikan nasional Indonesia.

Hal ini lah yang menjadi latarbelakang penulisan artikel ini dengan memaparkan konsep mengenai kebijakan pendidikan. Oleh sebab itu tujuan penulisan artikel ini adalah untuk mengkaji ruang lingkup kebijakan pendidikan yang terdiri dari makna kebijakan pendidikan, komponen kebijakan pendidikan, karakteristik kebijakan pendidikan dan implementasi kebijakan pendidikan.

\section{Pembahasan}

\section{Pengertian kebijakan pendidikan}

Kebijakan merupakan aktivitas politik yang dilaksanakan dengan sengaja berdasarkan pemikiran yang bijaksana dan terarah yang dilakukan oleh organisasi, lembagai maupun intansi pemerintah dalam memecahkan permasalahan untuk mendapatkan keputusan yang sesuai dengan tujuan (Risnawan, 2017). Setiap aspek kehidupan terdapat kebijakan masing-masing yang dijadikan pedoman dan panduan dalam melakukan aktivitas dan membatasi prilaku sehingga lebih jelas dan terarah. Kebijakan ini pun berlaku pada sistem pendidikan yang disebut dengan kebijakan pendidikan.

Kebijakan pendidikan ada dikarenakan munculnya permasalahan-permasalahan yang terjadi di bidang pendidikan (Sutapa, 2008). Permasalahan ini terjadi dikarenakan terdapatnya kesenjangan antara penyelenggara pendidikan dengan tujuan pendidikan (Suyahman, 2016). Kebijakan pendidikan merupakan sebuah aktivitas dalam merumuskan langkah maupun tahapan dalam penyelenggaraan pendidikan melalui penjabaran visi misi pendidikan yang bertujuan untuk mencapai tujuan pendidikan pada waktu tertentu (Fatkuroji, 2017). Selain itu ada juga yang berpendapat bahwa kebijakan pendidikan berhubungan dengan efektivitas dan efisiensi anggaran Pendidikan (Riant, 2008). Kebijakan pendidikan merupakan kebijakan publik yang mengelola khusus bidang pendidikan serta berhubungan dengan alokasi, penyerapan dan distribusi sumber pelaksanaan pendidikan maupun pengelolaan perilaku pendidikan (Bakry, 2010). Sehingga dapat disimpulkan bahwa kebijakan pendidikan merupakan kebijakan yang berhubungan dengan bidang pendidikan dalam proses penjabaran visi misi pendidikan agar tercapainya tujuan pendidikan melalui langkah strategis pelaksanaan pendidikan.

\section{Komponen Kebijakan Pendidikan}

Charles O. Jones (1979) menyatakan ada 5 komponen kebijakan pendidikan yaitu; 1) Goal (Tujuan). Tujuan diartikan sebagai hasil yang ingin didapatkan oleh individu maupun kelompok dalam rentang waktu yang ditetapkan. Tujuan dirancang sebagai langkah awal dalam merencanakan suatu kegiatan. Sebuah kebijakan pendidikan harus memiliki tujuan yang jelas agar proses penerapanya terarah. Tujuan kebijakan pendidikan harus dibuat rasional agar mudah diterima oleh berbagai pihak; 2) Plans (Rencana). Setelah tujuan pendidikan dirancang maka selanjutnya adalah membuat perencanaan kerja yang lebih spesifik agar dapat mencapai tujuan yang telah ditetapkan. Rencana kerja dibuat bertujuan untuk proses manejemen dan penerapan 
kebijakan pedidikan agar proses pengeimplementasianya terarah dan jelas; 3) Programme (Program). Setelah perencanaan kerja dibuat maka selanjutnya adalah proses pengembangan program. Program merupakan aktivitas berupa proyek yang nyata berdasarkan tujuan yang telah didesain sebelumnya. Program merupakan upaya yang dilakukan agar tercapainya tujuan dengan cara melihat tingkat keberhasilannya. Pembuatan kebijakan pendidikan diharapkan untuk dapat mengembangkan beberapa alternatif yang dapat dijadikan pertimbangan ketika proses pengambilan keputusan; 4) Decision (Keputusan). Keputusan merupakan sebagai bentuk tindakan dalam penentuan tujuan, pembuatan rencana program, pelaksanaan program, dan proses evaluasi program. Pengambilan keputusan dilakukan dengan mempertimbangkan hasil uji coba terhadap alternatif-alternatif kebijakan pendidikan. Hasil keputusan kebijakan pendidikan harus bersifat rasionalitas agar hasil tersebut dapat diterima oleh berbagai pihak; 5) Efects (Dampak). Dampak merupakan pengaruh yang ditimbulkan setelah kebijakan di laksanakan. Dampak ini dapat berupa sengaja maupun ketidaksengajaan baik berupan dampak priimer maupun dampak sekunder. Dampak juga dapat berupa dampak positif maupun dampak negatif.

Komponen-komponen ini lah yang dapat melahirkan sebuah kebijakan pendidikan. Tanpa adanya salah satu dari komponen tersebut maka tidak akan berjalannya kebijakan pendidikan. Kelima komponen ini saling berhubungan dan mendukung satu dengan yang lainnya.

\section{Karakteristik Kebijakan Pendidikan}

Kebijakan pendidikan memiliki karakteristik yang membedakannya dengan kebijakan lainnya. Adapun karakteristik kebijakan pendidikan yaitu:

\section{Memiliki tujuan pendidikan}

Sebuah kebijakan pendidikan harus memiliki tujuan khusus yang berhubungan dengan dunia pendidikan. Tujuan pendidikan yang disusun harus lebih terarah dan jelas serta memberikan gambaran mengenai kontribusi terhadap dunia pendidikan, (Lazwardi, 2017).

\section{Terpenuhinya aspek legal dan formal}

Sebelum kebijakan pendidikan di belakukan maka perlu dipenuhi prasyarat-prasyarat yang agar kebijakan tersebut berlaku sah dan diakui. Oleh sebab itu perlunya kebijakan tersebut di sah kan melalui persyaratan konstitusional berdasarkan hirarki konstitusi yang berlaku sehingga dilahirkan legimasi kebijakan pendidikan, (Anwar, 2017).

\section{Memiliki konsep operasional}

Kebijakan pendidikan merupakan seperangkat panduan yang bersofat umum. Maka sebuah kebijakan pendidikan harus memiliki manfaat operasional yang dapat diterapkan, (Solichin, 2015). Konsep operasional ini harus dimiliki agar pencapaian tujuan dapat di ukur secara jelas.

\section{Dibuat oleh yang berwenang}

Kebijakan pendidikan dirumuskan dan dibuat oleh par ahli yang memiliki hak dan wewnang dalam pembuatan kebijakan, (Heriawan, 2018). Hal ini bertujuan agar tidak timbulnya permasalahan baru yang dihasilkan dari kebijakan tersebut.

\section{Dapat dievaluasi}

Kebijakan pendidikan harus dapat dievaluasi. Suatu kebijakan apabila baik maka kebijakan tersebut dapat dikembangkan,(Lukitasari et al, 2017). Apabila kebijakan tersebut terdapat kesalahan maka harus dapat diperbaiki

\section{Memiliki sistematika}

Kebijakan pendidikan terdapat sistematika yang berhubungan dengan seluruh aspek yang terdapat didalamnya. Sistematika harus memperhatikan efisiensi, efektivitas dan keberlanjutan. Kebijakan juga harus bersifat tidak pragmatis dan deskriminatif. Kebijakan juga tidak boleh bersofat rapuh struktur, (Rahman, 2014). Hal ini agar kebijakan yang dilahirkan tidak mengalami kecacatan hukum baik secara internal maupun eksternal.

\section{Implementasi Kebijakan Pendidikan}

Dalam proses pembuatan kebijakan ada satu tahapan penting yang harus dilaksanakan yaitu implementasi kebijakan. Implementasi kebijakan merupakan sebuah proses dalam menerapkan kebijakan yang telah diesepakati dari beberbagai alternatif kebijakan yang telah di desain, (Akib, 2012). Jika dikaitkan dengan kebijakan pendidikan maka implementasi kebijakan pendidikan merupakan penerapan kebijakan pendidikan yang telah diputuskan bersama dari berbagai alternatif kebijakan pendidikan lainnya, (Sulistyadi, 2014). Implementasi kebijakan pendidikan merupakan keseluruhan kegiatan yang dilaksanakan oleh individu maupun sekelompok pemangku kepentingan untuk menerapkan kebijakan dalam mencapai tujuan 
pendidikan, (Prasojo, 2010). Maka dapat disimpulkan bahwa implementasi kebijakan pendidikan merupakan aktivitas dalam menerapkan kebijakan yang telah disepakati yang berguna untuk mencapai tujuan pendidikan.

Dalam proses implementasi kebijakan akan terlihat kendala atau permasalahan yang dihadapi dalam pencapain tujuan pendidikan. Dari semua rangkaian perumusan kebijakan pendidikan, maka proses implementasi ini lah yang menjadi tahapan yang lebih rumit dan kompleks. Hal ini dikarenakan perlunya kerjasama yang kuat antar elemen yang ada baik dari pihak pusat maupun elemen daerah.

Proses implementasi kebijakan pendidikan terdiri umumnya menggunakan empat pendekatan yaitu: 1) Pendekatan struktural. Pada hakikatnya pendekatan struktural bersifat top down. Pendekatan ini memandang bahwa perancangan, pengimplementasian dan proses evaluasi kebijakan pendidikan dilakukan secara struktutral serta sesuai dengan tingkatan maupun tahapannya, (Yuliah, 2020). Sehingga jika diamati bahwa pendekatan ini lebih bersifat birokratis dan cendrung kaku; 2) Pendekatan prosedural dan manajerial. Pendekatan prosedural dan manjerial lebih mementingkan prosedur dan teknik yang tepat dalam mengembangkan kebijakan dibandingkan penantaan struktur pelaksana, (Setyawan, 2014). Sehingga pendekatan ini membutuhkan alat teknologi dalam proses pengimplementasian kebijakan; 3) Pendekatan perilaku. Pendekatan perilaku memandang bahwa pelaksana kebijakan adalah prilaku manusia, (Machali, 2015). Implementasi kebijakan pendidikan akan terlaksana dengan baik apabila manusia juga memiliki prilaku yang baik; 4) Pendekakatan politik. Pendekatan politik lebih memfokuskan faktor politik penguasa dalam mempermudah maupun memperhambat penerapan kebijakan pendidikan, (Hartono, 2016). Pendekatan ini cendrung mempertimbangkan kenyataan politik yang terjadi.

Keempat pendekatan ini memiliki kelebihan dan kekurangan namun sehingga memerlukan kebijaksanaan dalam menggunakanya agar kebijakan pendidikan dapat mencapai tujuan pendidikan yang telah di tetapkan.

\section{Simpulan}

Kebijakan pendidikan merupakan kebijakan yang berhubungan dengan bidang pendidikan dalam proses penjabaran visi misi pendidikan agar tercapainya tujuan pendidikan melalui langkah strategis pelaksanaan pendidikan. Komponen kebijaka pendidikan terdiri dari lima yaitu tujuan, rencana, program, keputusan, dan dampak. Karakteristik kebijakan pendidikan yaitu memiliki tujuan pendidikan, memenuhi aspek legal-formal, memiliki konsep operasional, dibuat oleh yang berwenang, dapat dievaluasi dan memiliki sistematika.Pendekatan dalam pengimplementasian kebijakan pendidikan terdiri dari pendekatan struktural, pendekatan prosedural dan manejerial, pendekatan prilaku dan pendekatan politik.

\section{Referensi}

Akib, H. (2012). Implementasi kebijakan: Apa, mengapa dan bagaimana. Jurnal Ilmiah Ilmu Administrasi Publik, 1(1), 1-11.

Anwar, M. E. (2017). Menelusuri Kebijakan Pendidikan Islam di Indonesia. Edukasi Islami: Jurnal Pendidikan Islam, 3(05), 1-10.

Azhari, U. L., \& Kurniady, D. A. (2016). Manajemen pembiayaan pendidikan, fasilitas pembelajaran, dan mutu sekolah. Jurnal Administrasi Pendidikan, 23(2), 1-10.

Bakry, A. (2010). Kebijakan Pendidikan Sebagai Kebijakan Publik. Jurnal Medtek, 2(1), 1-13.

Dewi, R. (2016). Kebijakan pendidikan di tinjau dari segi hukum kebijakan publik. Jurnal Ilmu Hukum, 7(2), 58-71.

Fatkuroji, F. (2017). Implementasi Kebijakan Pembelajaran Terpadu dan Minat Pelanggan Pendidikan. Tarbawi: Jurnal Keilmuan Manajemen Pendidikan, 2(02), 28-40.

Hakim, L. (2016). Pemerataan akses pendidikan bagi rakyat sesuai dengan amanat Undang-Undang Nomor 20 Tahun 2003 tentang Sistem Pendidikan Nasional. EduTech: Jurnal Ilmu Pendidikan Dan Ilmu Sosial, 2(1), 1-10.

Hartono, Y. (2016). Pendidikan Dan Kebijakan Politik (Kajian Reformasi Pendidikan Di Indonesia Masa Orde Lama Hingga Reformasi). Agastya: Jurnal Sejarah Dan Pembelajarannya, 6(01), 35-45.

Heriawan, I. (2018). Kebijakan Pendidikan Provinsi (SLTA dan SMK) dan Analisis SWOT di Kalimantan Timur. Pendas Mahakam: Jurnal Pendidikan Dasar, 3(2), 98-116.

Jones, C. O. (1979). American politics and the organization of energy decision making. Annual Review of Energy, 4(1), 99-119.

Junaid, H. (2016). Sumber, Azas Dan Landasan Pendidikan (Kajian Fungsionalisasi secara makro dan mikro terhadap rumusan kebijakan pendidikan nasional). Sulesana: Jurnal Wawasan Keislaman, 7(2), 84-102. 
Kiwang, A. S., Pandie, D. B., \& Gana, F. (2014). Kebijakan Publik dan Efektivitas Organisasi. Jurnal Kebijakan Publik, 5(3), 31-36.

Lazwardi, D. (2017). Manajemen kurikulum sebagai pengembangan tujuan pendidikan. Al-Idarah: Jurnal Kependidikan Islam, 7(1), 119-125.

Lukitasari, S. W., Sulasmono, B. S., \& Iriani, A. (2017). Evaluasi implementasi kebijakan pendidikan inklusi. Kelola: Jurnal Manajemen Pendidikan, 4(2), 121-134.

Machali, I. (2015). Pendekatan Integrasi-Interkoneksi dalam Kajian Manajemen dan Kebijakan Pendidikan Islam. EL TARBAWI, 8(1), 32-53.

Nasarudin, T. M. (2016). Asas dan Norma Hukum Administrasi Negara Dalam Pembuatan Instrumen Pemerintahan. Jurnal Hukum Novelty, 7(2), 139-154.

Prasojo, L. D. (2010). Financial Resources Sebagai Faktor Penentu Dalam Implementasi Kebijakan Pendidikan. Jurnal Internasional Manajemen Pendidikan, 4(02), 1-10.

Rahman, H. (2014). Miskonsepsi Pendidikan Gratis. Jurnal Al-Qalam: Jurnal Kajian Islam \& Pendidikan, 6(1), $36-45$.

Riant, N. (2008). Kebijakan Pendidikan yang Unggul, Kasus Pembangunan Pendidikan di Kabupaten Jembrana, 2000-2006. Yogyakarta: Pustka Pelajar.

Risnawan, W. (2017). Peran dan Fungsi Infrastruktur Politik dalam Pembentukan Kebijakan Publik. Dinamika: Jurnal Ilmiah Ilmu Administrasi Negara, 4(3), 511-518.

Setiyawan, E. (2014). Implementasi Kebijakan Bantuan Pendidikan (Studi tentang Kebijakan Bantuan Pendidikan Masyarakat Kota Surakarta yang termuat dalam Peraturan Walikota Surakarta Nomor 11A Tahun 2012). Jurnal Administrasi Publik, 2(1), 122-128.

Solichin, M. (2015). Implementasi Kebijakan Pendidikan Dan Peran Birokrasi. Religi: Jurnal Studi Islam, 6(2), 148-178.

Sulistyadi, H. K. (2014). Implementasi kebijakan penyelenggaraan layanan pendidikan inklusif di Kabupaten Sidoarjo. Kebijakan Dan Manajemen Publik, 2(1), 1-10.

Sutapa, M. (2008). Kebijakan pendidikan dalam Perspektif Kebijakan Publik. Jurnal Manajemen Pendidikan $U N Y, 112408$.

Suyahman, S.(2016). Analisis Kebijakan Pendidikan Gratis Di Sekolah Menengah Atas Dalam Kaitannya Dengan Kualitas Pendidikan Menengah Atas. Jurnal Pendidikan Kewarganegaraan, 6(2), 1047-1054.

Yuliah, E. (2020). Implementasi Kebijakan Pendidikan. Jurnal At-Tadbir: Media Hukum dan Pendidikan, 30(2), 16-40. 